\title{
Optimal bone mechanical and material properties require a functional glucagon-like peptide-1 receptor
}

\author{
Guillaume Mabilleau ${ }^{1,2}$, Aleksandra Mieczkowska', Nigel Irwin ${ }^{3}$, Peter R Flatt ${ }^{3}$ \\ and Daniel Chappard ${ }^{1,2}$ \\ ${ }^{1}$ Groupe d'Etudes sur le Remodelage Osseux et les bioMatériaux (GEROM) - LHEA, ${ }^{2}$ Service Commun d'Imageries \\ et d'Analyses Microscopiques (SCIAM), IRIS-IBS Institut de Biologie en Santé, LUNAM Université, \\ CHU d'Angers, 49933 Angers Cedex, France \\ ${ }^{3}$ School of Biomedical Sciences, Ulster University, Coleraine, UK
}

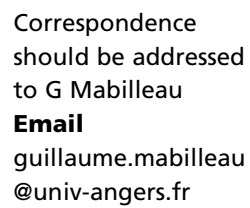

\begin{abstract}
Bone is permanently remodeled by a complex network of local, hormonal, and neuronal factors that affect osteoclast and osteoblast biology. Among these factors, a role for gastrointestinal hormones has been proposed based on the evidence that bone resorption dramatically falls after a meal. Glucagon-like peptide-1 (GLP1) is one of these gut hormones, and despite several reports suggesting an anabolic effect of GLP1, or its stable analogs, on bone mass, little is known about the effects of GLP1/GLP1 receptor on bone strength. In this study, we investigated by three-point bending, quantitative X-ray microradiography, microcomputed tomography, qBEl, and FTIRI bone strength and bone quality in male G/p1r knockout ( $G / p 1 r$ KO) mice when compared with control WT animals. Animals with a deletion of Glp1r presented with a significant reduction in ultimate load, yield load, stiffness, and total absorbed and post-yield energies when compared with WT animals. Furthermore, cortical thickness and bone outer diameter were significantly decreased in deficient animals. The mineral quantity and quality were not significantly different between Glp $1 \mathrm{r}$ KO and WT animals. On the other hand, the maturity of the collagen matrix was significantly reduced in deficient animals and associated with lowered material properties. Taken together, these data support a positive effect of GLP1R on bone strength and quality.
\end{abstract}
Key Words
- bone quality
- glucagon-like peptide-1
- bone strength
- bone matrix
- bone mineral

\section{Introduction}

Bone is a living mineralized material, highly complex and constantly remodeled in mass and architecture to adapt and repair the damage induced by growth, aging, and mechanical stress. In order to maintain a constant bone mass, bone remodeling necessitates a spatiotemporal coupling between osteoclasts, the bone-resorbing cells, and osteoblasts, the bone-forming cells. Bone remodeling is a complex process regulated by various stimuli that may affect osteoclast and osteoblast physiologies. A role for the gastrointestinal tract in bone remodeling has been suggested with evidence that modulation of serum markers of bone resorption is mirrored with the profile 
of gut hormone release after a meal (Henriksen et al. 2003, Elnenaei et al. 2010).

Glucagon-like peptide-1 (GLP1) is a gut hormone synthesized and secreted into the blood stream by intestinal endocrine $\mathrm{L}$ cells in response to a variety of stimuli (Wu et al. 2010). Biologically active GLP1 is secreted as a 7-37 or 7-36 amide peptide, which is rapidly inactivated to GLP1(9-36) by cleavage at the site of the second N-terminal alanine amino acid residue by the aminopeptidase, dipeptidyl peptidase IV (DPP-IV; Drucker $\&$ Nauck 2006). GLP1 action is tightly controlled by DPP-IV as more than $50 \%$ of GLP1 is inactivated before it reaches the systemic circulation and the half-life of circulating GLP1 is <2 min (Baggio \& Drucker 2007). Nevertheless, GLP1 binds to its receptor, the GLP1R, widely expressed in pancreatic islets, kidney, lung, heart, stomach, intestine, and the CNS, and this interaction results in activation of intracellular signaling (Campos et al. 1994, Bullock et al. 1996).

Although uncertainty persists in clearly demonstrating the expression of GLP1R in bone cells, administration of GLP1 or its enzyme-resistant analog exendin-4 for 3 days in normal and diabetic rats results in increased trabecular bone mass and augmentation of the expression of osteoblast markers in these animals, suggesting a possible anabolic effect of GLP1 on trabecular bone (Nuche-Berenguer et al. 2009, 2010). Using a model of GLP1 signaling deficiency, Yamada et al. (2008) reported that Glp1r knockout mice exhibit a trend for lower trabecular bone mass in the proximal metaphysis of the tibia. These authors also reported reduction in cortical bone mineral density (BMD) as evidenced by an experimental computed tomography (CT)-based densitometry. Taken together, all these data support an anabolic role of the GLP1/GLP1R pathway in bone. However, despite these observations, little is known about the impact of the GLP1/GLP1R on bone strength. Bone strength depends on bone and mineral quantity and also on structural and material properties of the bone matrix. Microarchitecture and material properties including degree of mineralization, mineral maturity, and collagen properties are known factors that influence bone strength (Chappard et al. 2011).

The aims of this study were to investigate bone strength and bone quality in Glp1r knockout male mice. Our results suggest that Glp1r-deficient male mice present with significant alterations of the cortical morphology and material properties that undoubtedly resulted in reduced bone strength. These findings support a positive role for GLP1/GLP1R pathway in controlling bone strength.

\section{Materials and methods}

\section{Animals}

Sixteen-week-old male mice presenting a deletion of Glp1r (kindly provided by Prof D J Drucker, Toronto, Canada) were used in this study. The background and generation of Glp1r-deficient mice used in this study were derived from an in-house breeding colony originally described elsewhere (Hansotia et al. 2004). Age-matched WT mice bred in-house with the same C57BL/6 genetic background were used as controls. A total of eight deficient and 15 control mice were used in this study. Animals were maintained on a $12 \mathrm{~h}$ light: $12 \mathrm{~h}$ darkness cycle in a temperature-controlled room $\left(21.5 \pm 1^{\circ} \mathrm{C}\right)$. Animals were individually caged and received food and water ad libitum. All experiments were conducted according to the UK Office regulations (UK Animals Scientific Procedures Act 1986) and European Union laws. Animals were killed by lethal inhalation of $\mathrm{CO}_{2}$ and left and right femurs were collected, cleaned of soft tissue. The left femurs were stored in $70 \%$ ethanol at $4{ }^{\circ} \mathrm{C}$ while the right femurs were frozen in a saline-soaked gauze and stored at $20{ }^{\circ} \mathrm{C}$ until use. Figure 1 describes the experimental design.

\section{Bone mechanical testing}

A three-point bending experiment was performed on the right femur. Before mechanical testing, the femurs were thawed overnight and rehydrated in saline for $24 \mathrm{~h}$ at room temperature as described elsewhere (Ammann et al. 2007). Three-point bending strength was measured with a constant span length of $10 \mathrm{~mm}$. The press head as well as the two support points were rounded to avoid shear load and cutting. The femurs were positioned horizontally with the anterior surface facing upward, centered on the

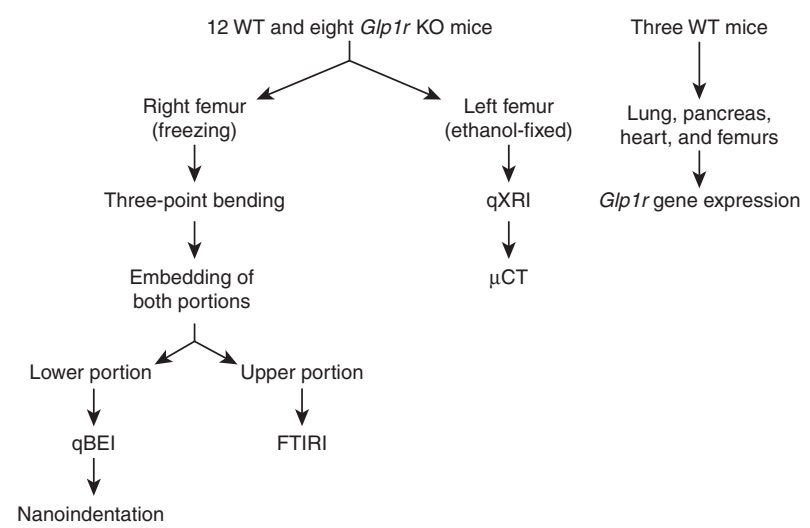

Figure 1

Schematic representation of the experimental design used in this study.

Published by Bioscientifica Ltd. 
support, and the pressing force was applied vertically to the midshaft of the bone. Each bone was tested with a loading speed of $2 \mathrm{~mm} / \mathrm{min}$ until failure with a $90 \mathrm{~N}$ load cell. The load-time curve obtained was converted into a load-displacement curve by the MTS TestSuite TW Software (MTS, Créteil, France). Ultimate load and ultimate displacement were respectively defined as the maximum load and maximum displacement recorded before breakdown of the bone. Stiffness was calculated as the slope of the elastic deformation of the bone. The total absorbed energy was defined as the total area under the loaddisplacement curve and represents the total energy absorbed by the midshaft femur. The yield was defined as the load necessary to initiate the transformation from elastic to plastic deformation. The post-yield energy was defined as the area under the load-displacement curve from yield until failure and represents the energy absorbed by bone during plastic deformation. Material properties such as ultimate strength, ultimate strain, elastic modulus, yield strength, breaking strength, and work to fracture have been calculated from mechanical parameters previously published (Turner \& Burr 1993, Ritchie et al. 2008).

\section{Quantitative X-ray microradiograph imaging}

Bone mineral content was determined using qXRI. Briefly, digital X-ray images of the left femur were recorded at a $12 \mu \mathrm{m}$ pixel resolution using a Faxitron MX20 device (Edimex, Angers, France) operating at $26 \mathrm{kV}$ and a $4 \times$ magnification. The region of interest was located $6 \mathrm{~mm}$ below the growth plate (midshaft of the femur) and represented a height of $2 \mathrm{~mm}$. The relative mineral content of calcified tissues was determined as reported by Bassett et al. (2012) with the following modifications. Briefly, a $1.5 \mathrm{~mm}$-thick steel plate, a $1.5 \mathrm{~mm}$ pure aluminum wire, and a $1.5 \mathrm{~mm}$-thick polyester plate were used on each microradiograph and served as standards. Before converting the 16-bit DICOM images into 8-bit Tiff images, the histogram was stretched from the polyester (gray level 0) to the steel (gray level 255) standards using Image J 1.45s (NIH, Bethesda, MD, USA). Increasing gradations of mineralization density were represented in 16 equal intervals using the 16-color lookup table in ImageJ 1.45s. The frequency of occurrence of an $i$ gray level $\left(F_{i}\right)$ was calculated as follows:

$F_{i}=100 \times \frac{N i}{N t}$,

where $\mathrm{Ni}$ represents the number of pixels with the $i$ gray level and $N t$ the total number of pixels. The frequency distribution as a function of gray level was plotted and the mean gray level $\left(\mathrm{GL}_{\text {mean }}\right)$ of each bone was deduced from this distribution using the following formula:

$\mathrm{GL}_{\text {mean }}=\frac{\sum\left(F_{i} \times \mathrm{GLi}\right)}{100}$,

where GLi represents the value of the $i$ gray level.

\section{X-ray microcomputed tomography}

X-ray microcomputed tomography (micro-CT) analysis was performed in the proximal left femur with a Skyscan 1172 microtomograph (Bruker Micro-CT, Kontich, Belgium) equipped with an X-ray tube working at $69 \mathrm{kV} / 100 \mu \mathrm{A}$. The pixel size was fixed at $3.75 \mu \mathrm{m}$, the rotation step at $0.25^{\circ}$, and exposure was done with a $0.5 \mathrm{~mm}$ aluminum filter. The volume of interest (VOI) was located $6 \mathrm{~mm}$ below the growth plate. The external bone diameter (B.Dm $(\mathrm{mm})$ ), marrow diameter (Ma.Dm $(\mathrm{mm}))$, cortical thickness $(\mathrm{Ct} . \mathrm{Th}(\mu \mathrm{m}))$, and cross-sectional moment of inertia (CSMI $\left.\left(\mathrm{mm}^{4}\right)\right)$ were measured with a laboratory-based routine made using Image $1.45 \mathrm{~s}$ according to the guidelines and nomenclature proposed by the American Society for Bone and Mineral Research (Bouxsein et al. 2010). 3D models represent a region of interest of $2 \mathrm{~mm}$ centered $6 \mathrm{~mm}$ below the growth plate.

\section{BMD distribution measured by backscattered electron imaging}

Quantitative backscattered electron imaging was employed to determine the BMD distribution (BMDD) as previously reported (Roschger et al. 1998, Gaudin-Audrain et al. 2013). Rapidly after three-point bending, lower portions of the right femur diaphysis were embedded undecalcified in methylmethacrylate at $4{ }^{\circ} \mathrm{C}$. Polymethylmethacrylate (pMMA) blocks were then polished to a $1 \mu \mathrm{m}$ finish with diamond particles, carbon-coated and observed with a scanning electron microscope (EVO LS10, Carl Zeiss Ltd., Nanterre, France) equipped with a five-quadrant semiconductor backscattered electron detector. The microscope was operated at $20 \mathrm{keV}$ with a probe current of $120 \mathrm{pA}$ and a working distance of $8.5 \mathrm{~mm}$. The backscattered signal was calibrated using pure carbon $(Z=6$, mean gray level $=25)$, pure aluminum $(Z=13$, mean gray level $=225)$, and pure silicium $(Z=14$, mean gray level $=253)$ standards (Micro-analysis Consultants Ltd., St Ives, UK). For these contrast/brightness settings, the back scattered electron (BSE) gray level histogram was converted into weight percentage of calcium. Eventual changes in

Published by Bioscientifica Ltd 
brightness and contrast due to instrument instabilities were checked by monitoring the current probe and imaging the reference material $(\mathrm{C}, \mathrm{Al}$, and $\mathrm{Si}$ ) every $15 \mathrm{~min}$. The cortical bone area was imaged at a $200 \times$ nominal magnification, corresponding to a pixel size of $0.5 \mu \mathrm{m} /$ pixel. The gray level distribution of each image was analyzed with a laboratory-made routine using ImageJ. Three variables were obtained from the BMDD: $\mathrm{Ca}_{\text {peak }}$ is the most frequently observed calcium concentration, $\mathrm{Ca}_{\text {mean }}$ is the average calcium concentration, and $\mathrm{Ca}_{\text {width }}$ is the width of the histogram at half maximum of the peak.

\section{Nanomechanical testing}

Nanoindentation tests evaluated the mechanical properties of the bone matrix. As nanoindentation assesses volume of material at a length scale less than that of individual microstructural features in bone, this technique avoids confounding factors such as bone microarchitecture and porosity that affect tissue properties at larger length scales such as three-point bending. Tests were performed on the same sample used for quantitative backscattered electron imaging (qBEI) measurements after rapid polishing. Briefly, femurs were rehydrated overnight in saline prior to nanoindentation testing. Eight indents were positioned in cortical bone $6 \mathrm{~mm}$ below the growth plate with a NHT-TTX System (CSM, Peseux, Switzerland) equipped with a Berkowitch diamond probe. The indents were done up to a depth of $900 \mathrm{~nm}$ with a loading/unloading rate of $40 \mathrm{mN} / \mathrm{min}$. At maximum load, a holding period of $15 \mathrm{~s}$ was applied to avoid creeping of the bone material. Maximum load, indentation modulus, hardness, and dissipated energy were determined according to Oliver \& Pharr (1992).

\section{Fourier transformed infrared spectroscopy}

After three-point bending, upper portions of the femur diaphysis were embedded in pMMA at $4{ }^{\circ} \mathrm{C}$. Sections of $4 \mu \mathrm{m}$ thickness were cut dry on a heavy-duty microtome equipped with tungsten carbide knives (Leica Polycut $S$ ) and sandwiched between $\mathrm{BaF}_{2}$ optical windows. Spectral analysis was obtained on a Bruker Vertex 70 spectrometer (Bruker Optics, Ettlingen, Germany) interfaced with a Bruker Hyperion 3000 infrared microscope equipped with a standard single-element Mercury Cadmium Telluride (MCT) detector $\left(750-4000 \mathrm{~cm}^{-1}\right)$. Infrared spectra were recorded at a resolution of $4 \mathrm{~cm}^{-1}$, with an average of 32 scans in transmission mode. Background spectral images were collected under identical conditions from the same
$\mathrm{BaF}_{2}$ windows at the beginning and at the end of each experiment to ensure instrument stability. For Fourier transformed infrared spectroscopy (FTIR) analysis, ten spectra were acquired $\sim 6 \mathrm{~mm}$ below the growth plate on cortical bone, corresponding to the fracture zone observed by three-point bending, and analyzed with the Opus Software (release 5.5, Bruker). The contribution of the embedding pMMA and water vapor were corrected for each spectrum prior to baseline correction. Then, individual spectra have been subjected to curve fitting using a commercially available software package (Grams/AI 8.0, ThermoFisher Scientific, Villebon sur Yvette, France). Briefly, using the Levenberg-Maquardt algorithm, every absorption band is characterized by its area. The secondderivative spectrum was used to determine the number and the position of the bands constituting every spectral interval. All bands were positioned at maximal intensities with a Gaussian shape. Position, height, width at half intensity, and area were obtained. Peaks corresponding to amide I and II (1350-1725 $\left.\mathrm{cm}^{-1}\right)$ and 0103 phosphate (900-1200 $\mathrm{cm}^{-1}$ ) were considered for further analysis. The evaluated IR spectral parameters were i) mineral-to-matrix ratio, which reflects the degree of mineralization of the bone matrix, calculated from the ratio of integrated areas of the phosphate $u 1, u 3$ band at $900-1200 \mathrm{~cm}^{-1}$ to the amide I band at $1585-1725 \mathrm{~cm}^{-1}$; ii) mineral maturity, which reflects the ratio of apatic vs nonapatic domains, calculated as the ratio of the relative intensity of sub-bands at 1020 and $1030 \mathrm{~cm}^{-1}$ of the phosphate band (Paschalis et al. 1996); iii) carbonate-to-phosphate ratio was expressed by the ratio of integrated areas of the $\cup 2 \mathrm{CO}_{3}^{2-}$ region $\left(850-890 \mathrm{~cm}^{-1}\right)$ to the $u 1, u 3$ phosphate band (900-1200 $\mathrm{cm}^{-1}$ ) (Boskey et al. 2005); and iv) collagen maturity, determined as the relative ratio of sub-bands located at 1660 and $1690 \mathrm{~cm}^{-1}$ of the amide I peak. Although multiple theories about the significance of this ratio (pyridinium trivalent to dehydrodihydroxylysinonorleucine divalent collagen cross-links, modifications of secondary structure of collagen molecules) exist, this ratio indicates the maturity of the collagen of the bone matrix (Paschalis et al. 2001, Farlay et al. 2011).

\section{Gene expression}

Bone marrow cells were isolated from the long bones of 16-week-old WT animals by flushing tibias and femurs with $\alpha$-MEM as previously reported (Mieczkowska et al. 2012). For osteoblast differentiation, bone marrow cells were plated into a $25 \mathrm{~cm}^{2}$ culture flask until confluency ( $~ 3$ days). For osteoclast culture, bone marrow cells were

Published by Bioscientifica Ltd. 
cultured for $24 \mathrm{~h}$ into a $25 \mathrm{~cm}^{2}$ flask in $\alpha$-MEM supplemented with $10 \%$ FCS, $2 \mathrm{mM}$ L-glutamine, $100 \mathrm{U} / \mathrm{ml}$ penicillin, and $100 \mu \mathrm{g} / \mathrm{ml}$ streptomycin to allow stromal cell attachment. Non-adherent cells were then collected and plated in 24-well plate in $\alpha$-MEM supplemented with $10 \%$ FCS, $2 \mathrm{mM}$ L-glutamine, $100 \mathrm{U} / \mathrm{ml}$ penicillin, $100 \mu \mathrm{g} / \mathrm{ml}$ streptomycin, $25 \mathrm{ng} / \mathrm{ml}$ macrophage colonystimulating factor (R\&D Systems, Abingdon, UK), and $50 \mathrm{ng} / \mathrm{ml}$ soluble RANKL (Peprotech Ltd., London, UK). After 7 days of culture, multinucleated osteoclasts were evidenced in culture as previously described (Mabilleau et al. 2011). Total RNA were extracted from osteoblast or osteoclast ex vivo cultures, lung, pancreatic islets, and heart using TRIzol; reversed transcribed using iScript cDNA synthesis kit (Bio-Rad); and amplified by real-time PCR using SYBR GREEN PCR master mix (Bio-Rad). The mouse Glp1r mRNA transcript was amplified by quantitative PCR using primer pairs $5^{\prime}$-GGGTCTCTGGCTACATAAGGACAAC- $3^{\prime}$ and $5^{\prime}$-AAGGATGGCTGAAGCGATGAC- $3^{\prime}$. The expression level of each sample was normalized against Gapdh mRNA expression using primer pairs 5'-AATG-

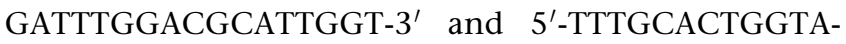
CGTGTTGAT-3'.

\section{Statistical analysis}

Results were expressed as mean \pm s.E.M. Non-parametric Mann-Whitney $U$ test was used to compare the differences between the groups using the Systat Statistical Software release 13.0 (Systat Software, Inc., San Jose, CA, USA). Correlation between material properties and collagen cross-link ratio was assessed by a least squares linear regression analysis. Differences at $P<0.05$ were considered significant.

\section{Results}

\section{GLP1R is required for optimum bone strength}

Bone strength of the femur was assessed by three-point bending and the results are presented Table 1. In Glp1r KO mice, mechanical parameters such as ultimate load, yield load, stiffness, total absorbed, and post-yield energies were reduced significantly by $17,21,25,34$, and $26 \%$ respectively when compared with WT animals. No differences in ultimate displacement were observed between these two groups of animals. Material properties such as work to fracture and yield strength were significantly reduced in Glp1r-deficient mice by 20, 20, and $7 \%$ respectively when compared with WT mice. No
Table 1 Three-point bending parameters in WT and Glp $1 r$ KO mice

\begin{tabular}{|c|c|c|c|}
\hline & WT $(n=12)$ & Glp1r KO $(n=8)$ & $P$ value \\
\hline 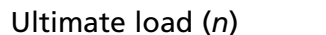 & $14.47 \pm 0.35$ & $11.95 \pm 0.27$ * & 0.034 \\
\hline $\begin{array}{l}\text { Ultimate displacement } \\
(\mathrm{mm})\end{array}$ & 06 & & 1.000 \\
\hline Stiffness (N/mm) & $42.68+0.85$ & $31.92+5.45 *$ & 0.05 \\
\hline orbed energy & & & \\
\hline Yield load $(n)$ & $11.83 \pm 0.45$ & $9.37 \pm 0.42 *$ & 0.021 \\
\hline $\begin{array}{l}\text { Post-yi } \\
\text { (N.m }\end{array}$ & & & \\
\hline strength & $84.2 \pm 2.0$ & -2 & 0.513 \\
\hline strength & $0.9 \pm 3$ & - & 33 \\
\hline ctrain & 0.013 & 0.01 & \\
\hline Ela & & & \\
\hline $\begin{array}{l}\text { Work to fracture } \\
\left(\mathrm{KJ} / \mathrm{m}^{2}\right)\end{array}$ & $0.211 \pm$ & 0.168 & 0.047 \\
\hline Yield strength (MPa) & 69.3 & 64.2 & 0.05 \\
\hline
\end{tabular}

${ }^{*} P<0.05$ vs WT animals.

significant differences were observed for ultimate strength, breaking strength, ultimate strain, and elastic modulus.

Glp1r deficiency results in altered femoral mineral density and cortical geometry

As represented in Fig. 2A, the bone mineral content seemed to be lower in Glp1r $\mathrm{KO}$ animals and indeed, the frequency of occurrence of gray level, representing the bone mineral content, was switched toward the left in Glp1r KO mice, indicating a lower bone mineral content. Furthermore, the mean gray level was significantly reduced by $5.2 \%$ in Glp1r KO mice when compared with WT controls $(P=0.021)$. Histomorphometric analysis of cortical bone (Fig. 2B) revealed that B.Dm was reduced significantly by $6 \%$ in Glp1r $\mathrm{KO}$ animals when compared with WT controls $(P=0.034)$ while Ma.Dm was unchanged $(P=0.289)$. Consequently, Ct.Th and CSMI were lowered significantly by 13 and $25 \%$ respectively in deficient animals when compared with WT $(P=0.034$ and $P=0.031$ respectively).

\section{Nanomechanical properties of the bone matrix are reduced in Glp1r KO mice}

When compared with WT animals, Glp1r-deficient animals exhibited a significant $19 \%$ decrease in maximum load, as well as a significant reduction in bone matrix hardness ( $-19 \%$; Table 2$)$. The indentation modulus was

Published by Bioscientifica Ltd 

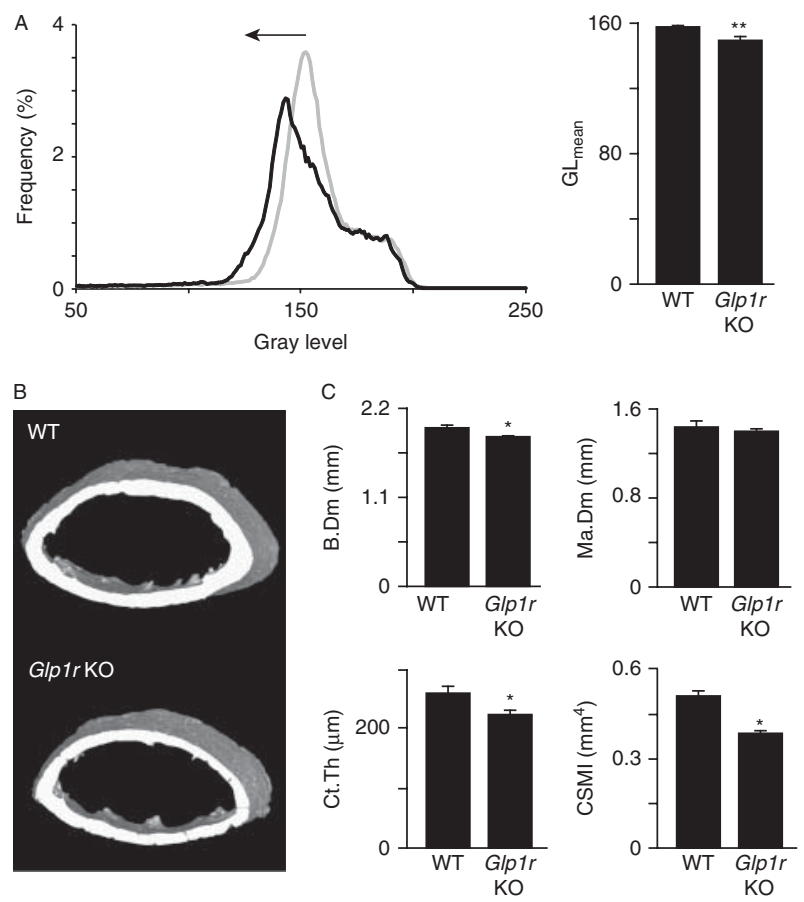

Figure 2

Bone mineral content and cortical bone morphology are altered in G/p1r $\mathrm{KO}$ animals. (A) Bone mineral content as determined by quantitative $\mathrm{X}$-ray microradiograph is reduced in G/p1r KO animals (black line and bar) as determined by a shift to the left of the frequency of occurrence of gray pixel and lower value of $\mathrm{GL}_{\text {mean }}$ when compared with WT (gray line and bar). (B) 3D models of WT and GIp1r KO femurs and (C) histomorphometric analysis of cortical bone in WT and Glp $1 r$ KO mice. ${ }^{*} P<0.05$ vs WT animals and $* * P<0.01$ vs WT animals.

unchanged between the two groups of animals but the energy dissipated was significantly reduced by $15 \%$ in Glp1r-deficient mice.

\section{Collagen maturation but not mineral maturation is altered in Glp1r KO mice}

The BMDD in the bone matrix was investigated by qBEI in WT and Glp1r KO mice (Table 3). Interestingly, no differences were observed between the two groups of animals in any of the studied parameters, indicating that the profile of mineralization of the bone matrix was similar in both cases. Similarly, the mineral-to-matrix ratio determined from FTIR measurements was not significantly different between WT and $G l p 1 r^{-/-}$animals (Fig. 3A). The mineral maturity and carbonate content were unchanged in $\mathrm{Glp}_{\mathrm{p}} \mathrm{r}^{-/-}$animals when compared with WT animals $(P=0.221$ and $P=0.536$ respectively). On the other hand, the ratio of trivalent mature over divalent immature collagen cross-links was significantly decreased by $15 \%$ in $G l p 1 r^{-/-}$mice when compared with WT $(P=0.007$, Fig. 3D). As shown in Fig. 4 , a positive correlation $\left(R^{2}=0.62, P<0.004\right)$ was found between dissipated energy assessed by nanoindentation and the $1660: 1690 \mathrm{~cm}^{-1}$ ratio assessed by FTIR. However, no significant correlations were found between maximum load or hardness with the $1660: 1690 \mathrm{~cm}^{-1}$ ratio $\left(R^{2}=0.33\right.$, $P=0.067$ and $R^{2}=0.13, P=0.268$ respectively).

\section{GLP1R is not expressed in bone cells}

As expected, a strong expression of GLP1R was found in lung and pancreatic islets and to a lower extent in heart (Fig. 5). On the other hand, Glp1r transcripts were not found in either osteoblasts or osteoclasts.

\section{Discussion}

In this study, we investigated bone strength in a mouse model of Glp1r deficiency to understand how the GLP1/GLP1R pathway may affect bone strength. Threepoint bending experiments, performed on the midshaft femur, revealed a significant decrease in the total absorbed energy as well as reduction in ultimate load, stiffness, yield load, post-yield energy, work to fracture, and yield strength. These results suggest reduced bone strength in these animals. However, several factors might influence the outcome of three-point bending including bone microarchitecture and bone material properties (Turner $\&$ Burr 1993). Indeed, material properties calculated from stress-strain curves indicated that work to fracture and yield strength were significantly reduced in deficient animals but not ultimate strength or strain or the elastic modulus. Taken together, these data indicate that cortical bone morphology and material properties may be altered. In the C57BL/ 6 mouse strain, at the midshaft femur, bone tissue is composed almost exclusively of cortical bone (Judex et al. 2004, Bouxsein et al. 2005). A study conducted by Yamada et al. (2008) reported a reduction in cortical

Table 2 Nanomechanical properties of the bone matrix

\begin{tabular}{|c|c|c|c|}
\hline & WT $(n=12)$ & GIp1r KO $(n=8)$ & $P$ value \\
\hline Maximum load (mN) & $11.9 \pm 0.6$ & $9.9 \pm 0.4^{*}$ & 0.037 \\
\hline Hardness (MPa) & $627.8 \pm 34.4$ & $510.7 \pm 28.9 *$ & 0.028 \\
\hline $\begin{array}{l}\text { Indentation modulus } \\
\quad(\mathrm{GPa})\end{array}$ & $12.9 \pm 0.6$ & $12.1 \pm 0.4$ & 0.203 \\
\hline $\begin{array}{l}\text { Dissipated energy } \\
(\mathrm{mN} . \mathrm{nm})\end{array}$ & $3189.7 \pm 176.7$ & $2708.6 \pm 130.9 *$ & 0.028 \\
\hline
\end{tabular}

Published by Bioscientifica Ltd 
Table 3 Bone mineral density distribution in WT and Glp1r-deficient mice

\begin{tabular}{|c|c|c|c|}
\hline & WT $(n=12)$ & GIp1r KO $(n=8)$ & $P$ value \\
\hline$C a_{\text {peak }}(\%)$ & $26.9 \pm 0.7$ & $26.8 \pm 0.7$ & 1.00 \\
\hline$C a_{\text {mean }}(\%)$ & $26.3 \pm 0.6$ & $26.3 \pm 0.7$ & 0.936 \\
\hline Ca width $(\%)$ & $2.7 \pm 0.1$ & $2.9 \pm 0.2$ & 0.337 \\
\hline
\end{tabular}

BMD in the same $G l p 1 r^{-/-}$mice model in the tibia. In this study, cortical bone morphology was investigated by micro-CT and significant reductions in bone outer diameter, Ct.Th, and CSMI were observed in $G l p 1 r^{-/-}$ mice. Interestingly, Ct.Th diminution was associated with a decrease in the outer bone diameter while the marrow diameter was unchanged. Furthermore, gene expression analysis revealed that the GLP1R is not expressed in bone cells, suggesting that the decrease in bone strength and quality observed in this animal model may be a consequence of Glp1r deletion in other tissues rather than a direct effect on bone cells.

Indeed, GLP1R is expressed in paraventricular, arcuate, and dorsomedial nuclei of the hypothalamus (Merchenthaler et al. 1999). Some of these regions have been implicated in the central control of bone remodeling by targeting osteoblasts, and as such, alterations of bone quality could also result from activation/inactivation of specific central relays. Furthermore, these mice present with a mild glucose intolerance represented by fasting hyperglycemia (Ayala et al. 2010). Regarding the beneficial role of insulin in bone growth and or quality, dysregulation of insulin action in these mice may also represent another mechanism leading to the observed phenotype. Furthermore, alterations of IGF1R expression have been noted in these mice (Cornu et al. 2009) and could also participate to the reduction in bone diameter and hence bone quality. GLP1R is also expressed in C cells of the thyroid gland and exerts, when activated by GLP1 or its stable analogs, a stimulating effect on calcitonin secretion in rodents (Bjerre Knudsen et al. 2010). Calcitonin is one of the most efficient inhibitors of bone resorption in vitro (Zaidi et al. 1990, Moonga et al. 1992). Evidence from previous studies suggests that basally, male Glp1r KO mice present with a 2.5-fold increase in circulating plasma calcitonin (Madsen et al. 2012). As regard to the inhibitory action of calcitonin on bone resorption, it would be legitimate to hypothesize that bone resorption should be the primary target of calcitonin increase. However, recent evidence made with genetic ablation of either the calcitonin or calcitonin receptor genes highlighted an unexpected phenotype of high bone mass with no or little apparent effect on bone resorption (Hoff et al. 2002, Dacquin et al. 2004, Davey et al. 2008). This unexpected phenotype indicated a possible inhibitory action (direct or indirect) of calcitonin on bone formation without affecting bone resorption. Therefore, the contributing effect of increased circulating calcitonin to bone formation in our Glp1r KO model remains a possible scenario.

Another factor that strongly affects bone strength is the quality of bone matrix (Ammann et al. 2007). Glp1r KO mice presented with a decrease in maximum load $(-17 \%)$, hardness $(-19 \%)$, and dissipated energy $(-15 \%)$. Owing to the nanocomposite composition of the bone matrix, any of the collagen or mineral might be involved in the reduction in material properties. Investigation of the bone mineral, by qBEI and FTIR, revealed that neither the degree of mineralization nor the maturity of the mineral was affected by the Glp1r deletion. However, it is important to bear in mind that due to instrument
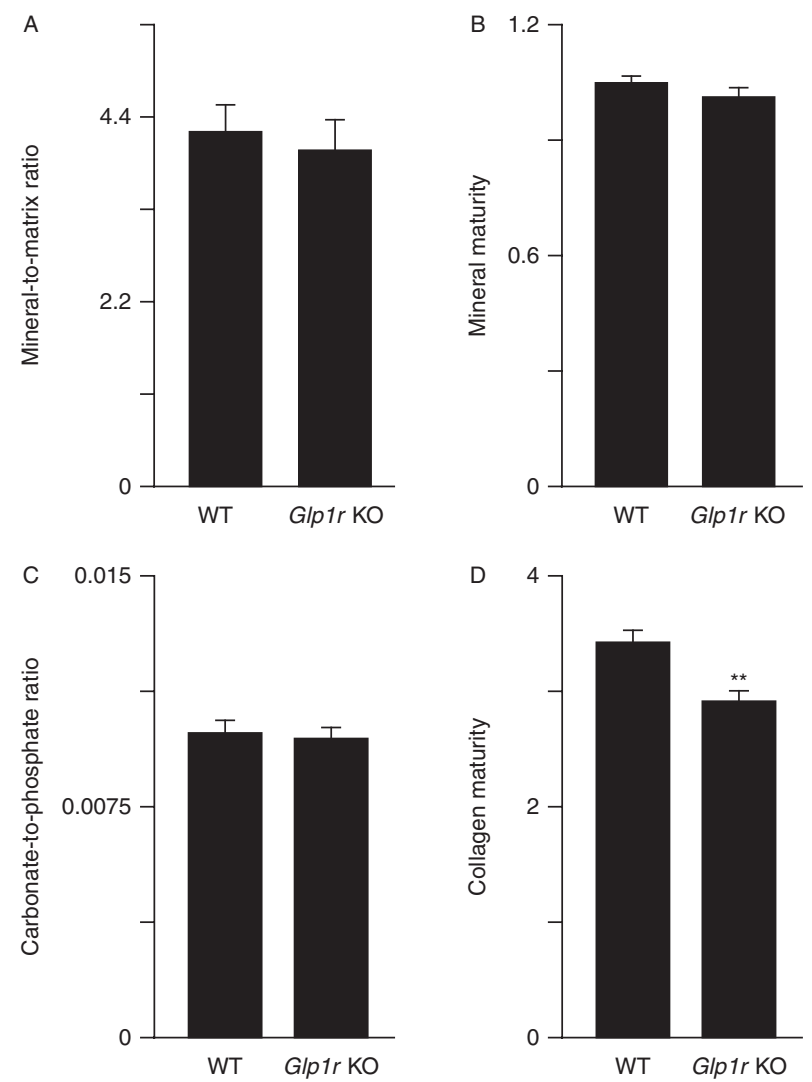

Figure 3

FTIR assessment of bone matrix properties. (A) Mineral-to-matrix ratio, (B) mineral maturity, (C) carbonate content, and (D) collagen maturity. $* * P<0.01$ vs WT animals.

Published by Bioscientifica Ltd. 

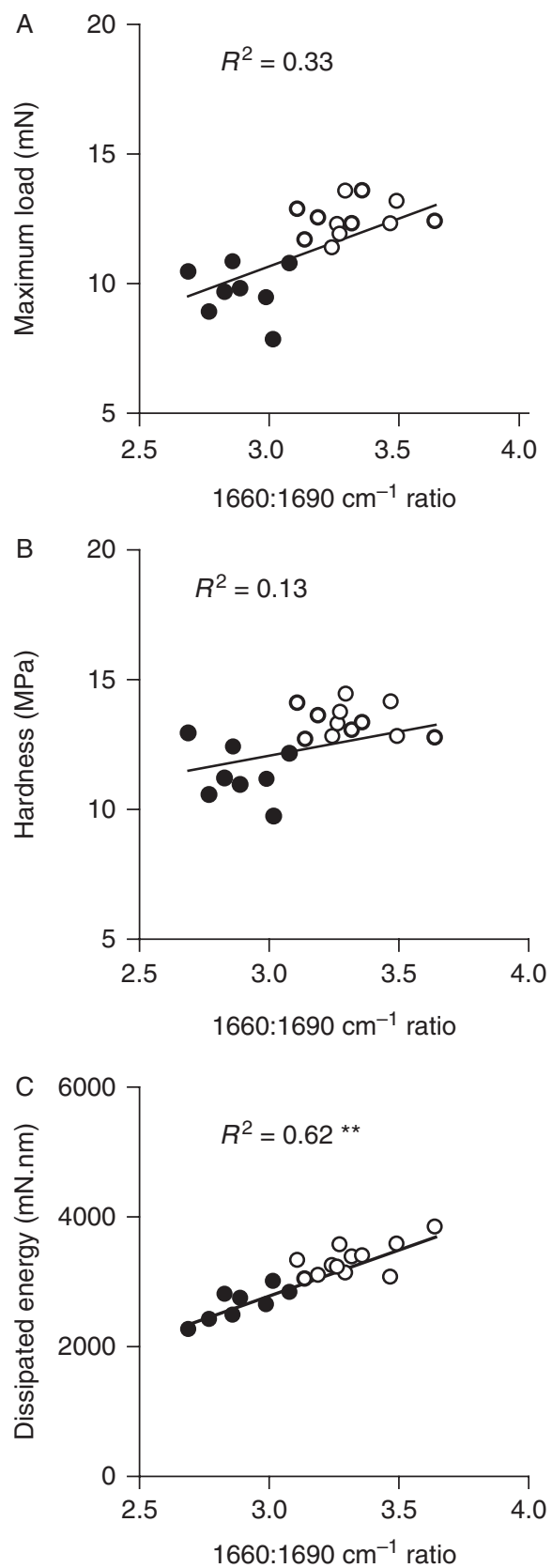

Figure 4

Regression analysis between maximum load (A), hardness (B), and dissipated energy (C) and 1660:1690 $\mathrm{cm}^{-1}$ ratio. Open circles, WT and closed circles, Glp1r KO mice. $* * P<0.01$ vs WT.

limitations, we were not capable of investigating mineral crystallinity as proposed by Farlay et al. (2010). On the other hand, the maturity of the collagen matrix, determined as the $1660: 1690 \mathrm{~cm}^{-1}$ ratio, was significantly reduced. Some controversies exist in the interpretation of this ratio as some groups reported that this ratio represent the trivalent over divalent cross-links ratio, but recently, an elegant study of Farlay and collaborators demonstrated that variation in this parameter could be more related to secondary structure of the collagen matrix after mineralization than a ratio of trivalent over divalent collagen cross-links (Farlay et al. 2011). Nevertheless, it is an indicator of collagen maturity. The reduction of collagen maturity could itself explain the reduction in material properties, as we found a significant positive association between collagen maturity and dissipated energy. Furthermore, alteration of the collagen matrix often alters the post-yield properties of the bone matrix (Bailey et al. 1999, Zioupos et al. 1999, Burr 2002). In our study, the observed reduction in mature trivalent cross-links could also account for the decreased post-yield energy determined by three-point bending.

In conclusion, mice lacking the GLP1R appear to have a decrease in bone strength observed at the anatomical level with a decrease in three-point bending resistance and decreased Ct.Th. Bone strength was also reduced at the tissue level and was associated with reductions of collagen cross-linking, but no alteration of the bone mineral. Overall, these data support a beneficial role for the GLP1/GLP1R signaling pathway in bone quality. This is important regarding the introduction of GLP1 mimetics for the treatment of patients with type 2 diabetes mellitus.

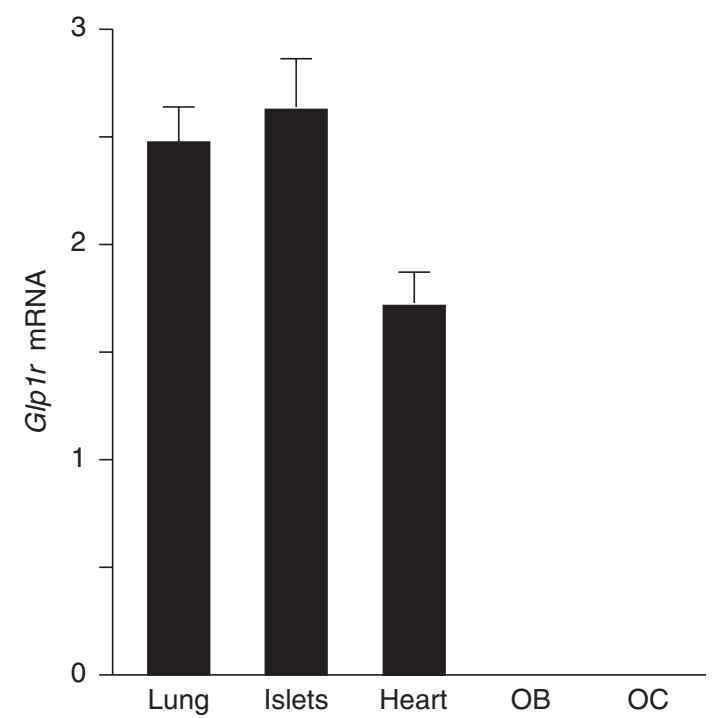

Figure 5

Expression of Glp1r gene in mice. RT-PCR analysis was performed using RNA prepared from lung, pancreatic islets, heart, and ex vivo culture of osteoblasts and osteoclasts from WT mice. Results were normalized relative to levels of Gapdh mRNA transcripts in the same sample. Data are mean \pm s.E.M., $n=3$.

Published by Bioscientifica Ltd. 


\section{Declaration of interest}

The authors declare that there is no conflict of interest that could be perceived as prejudicing the impartiality of the research reported.

\section{Funding}

This work was supported by grants from Contrat Région Pays de la Loire: Bioregos2 program and the University of Ulster Proof of Principle Funding Programme.

\section{Acknowledgements}

The authors are grateful to N Gaborit and G Brossard for their help with micro-CT. The authors would also like to acknowledge Mr Stéphane Blouin (Vienna, Austria) for fruitful discussion on FTIR methodology and measurements and Prof. D J Drucker (Toronto, Canada) for kindly providing the Glp1r KO mice.

\section{References}

Ammann P, Badoud I, Barraud S, Dayer R \& Rizzoli R 2007 Strontium ranelate treatment improves trabecular and cortical intrinsic bone tissue quality, a determinant of bone strength. Journal of Bone and Mineral Research 22 1419-1425. (doi:10.1359/jbmr.070607)

Ayala JE, Bracy DP, James FD, Burmeister MA, Wasserman DH \& Drucker DJ 2010 Glucagon-like peptide-1 receptor knockout mice are protected from high-fat diet-induced insulin resistance. Endocrinology 151 4678-4687. (doi:10.1210/en.2010-0289)

Baggio LL \& Drucker DJ 2007 Biology of incretins: GLP-1 and GIP. Gastroenterology 132 2131-2157. (doi:10.1053/j.gastro.2007.03.054)

Bailey AJ, Sims TJ, Ebbesen EN, Mansell JP, Thomsen JS \& Mosekilde L 1999 Age-related changes in the biochemical properties of human cancellous bone collagen: relationship to bone strength. Calcified Tissue International 65 203-210. (doi:10.1007/s002239900683)

Bassett JH, van der Spek A, Gogakos A \& Williams GR 2012 Quantitative X-ray imaging of rodent bone by Faxitron. Methods in Molecular Biology 816 499-506. (doi:10.1007/978-1-61779-415-5_29)

Bjerre Knudsen L, Madsen LW, Andersen S, Almholt K, de Boer AS, Drucker DJ, Gotfredsen C, Egerod FL, Hegelund AC, Jacobsen H et al. 2010 Glucagon-like peptide-1 receptor agonists activate rodent thyroid C-cells causing calcitonin release and C-cell proliferation. Endocrinology 151 1473-1486. (doi:10.1210/en.2009-1272)

Boskey AL, DiCarlo E, Paschalis E, West P \& Mendelsohn R 2005 Comparison of mineral quality and quantity in iliac crest biopsies from high- and low-turnover osteoporosis: an FT-IR microspectroscopic investigation. Osteoporosis International 16 2031-2038. (doi:10.1007/ s00198-005-1992-3)

Bouxsein ML, Myers KS, Shultz KL, Donahue LR, Rosen CJ \& Beamer WG 2005 Ovariectomy-induced bone loss varies among inbred strains of mice. Journal of Bone and Mineral Research 20 1085-1092. (doi:10.1359/ JBMR.050307)

Bouxsein ML, Boyd SK, Christiansen BA, Guldberg RE, Jepsen KJ \& Muller R 2010 Guidelines for assessment of bone microstructure in rodents using micro-computed tomography. Journal of Bone and Mineral Research $\mathbf{2 5}$ 1468-1486. (doi:10.1002/jbmr.141)

Bullock BP, Heller RS \& Habener JF 1996 Tissue distribution of messenger ribonucleic acid encoding the rat glucagon-like peptide-1 receptor. Endocrinology 137 2968-2978. (doi:10.1210/en.137.7.2968)

Burr DB 2002 The contribution of the organic matrix to bone's material properties. Bone 31 8-11. (doi:10.1016/S8756-3282(02)00815-3)

Campos RV, Lee YC \& Drucker DJ 1994 Divergent tissue-specific and developmental expression of receptors for glucagon and glucagon-like peptide-1 in the mouse. Endocrinology 134 2156-2164. (doi:10.1210/ en.134.5.2156)

Chappard D, Basle MF, Legrand E \& Audran M 2011 New laboratory tools in the assessment of bone quality. Osteoporosis International 22 2225-2240. (doi:10.1007/s00198-011-1573-6)

Cornu M, Yang JY, Jaccard E, Poussin C, Widmann C \& Thorens B 2009 Glucagon-like peptide- 1 protects $\beta$-cells against apoptosis by increasing the activity of an IGF-2/IGF-1 receptor autocrine loop. Diabetes $\mathbf{5 8}$ 1816-1825. (doi:10.2337/db09-0063)

Dacquin R, Davey RA, Laplace C, Levasseur R, Morris HA, Goldring SR, Gebre-Medhin S, Galson DL, Zajac JD \& Karsenty G 2004 Amylin inhibits bone resorption while the calcitonin receptor controls bone formation in vivo. Journal of Cell Biology 164 509-514. (doi:10.1083/ jcb.200312135)

Davey RA, Turner AG, McManus JF, Chiu WS, Tjahyono F, Moore AJ, Atkins GJ, Anderson PH, Ma C, Glatt V etal. 2008 Calcitonin receptor plays a physiological role to protect against hypercalcemia in mice. Journal of Bone and Mineral Research 23 1182-1193. (doi:10.1359/jbmr.080310)

Drucker DJ \& Nauck MA 2006 The incretin system: glucagon-like peptide-1 receptor agonists and dipeptidyl peptidase- 4 inhibitors in type 2 diabetes. Lancet 368 1696-1705. (doi:10.1016/S0140-6736(06)69705-5)

Elnenaei MO, Musto R, Alaghband-Zadeh J, Moniz C \& Le Roux CW 2010 Postprandial bone turnover is independent of calories above $250 \mathrm{kcal}$. Annals of Clinical Biochemistry 47 318-320. (doi:10.1258/acb.2010. 010010)

Farlay D, Panczer G, Rey C, Delmas PD \& Boivin G 2010 Mineral maturity and crystallinity index are distinct characteristics of bone mineral. Journal of Bone and Mineral Metabolism 28 433-445. (doi:10.1007/ s00774-009-0146-7)

Farlay D, Duclos ME, Gineyts E, Bertholon C, Viguet-Carrin S, Nallala J, Sockalingum GD, Bertrand D, Roger T, Hartmann DJ et al. 2011 The ratio $1660 / 1690 \mathrm{~cm}(-1)$ measured by infrared microspectroscopy is not specific of enzymatic collagen cross-links in bone tissue. PLOS ONE 6 e28736. (doi:10.1371/journal.pone.0028736)

Gaudin-Audrain C, Irwin N, Mansur S, Thorens B, Flatt PR, Basle MF, Chappard D \& Mabilleau G 2013 Glucose-dependent insulinotropic polypeptide receptor deficiency leads to modifications of trabecular bone mass and quality in mice. Bone 53 221-230. (doi:10.1016/j.bone. 2012.11.039)

Hansotia T, Baggio LL, Delmeire D, Hinke SA, Yamada Y, Tsukiyama K, Seino Y, Holst JJ, Schuit F \& Drucker DJ 2004 Double incretin receptor knockout (DIRKO) mice reveal an essential role for the enteroinsular axis in transducing the glucoregulatory actions of DPP-IV inhibitors. Diabetes 53 1326-1335. (doi:10.2337/diabetes.53.5.1326)

Henriksen DB, Alexandersen P, Bjarnason NH, Vilsboll T, Hartmann B, Henriksen EE, Byrjalsen I, Krarup T, Holst JJ \& Christiansen C 2003 Role of gastrointestinal hormones in postprandial reduction of bone resorption. Journal of Bone and Mineral Research 18 2180-2189. (doi:10.1359/jbmr.2003.18.12.2180)

Hoff AO, Catala-Lehnen P, Thomas PM, Priemel M, Rueger JM, Nasonkin I, Bradley A, Hughes MR, Ordonez N, Cote GJ et al. 2002 Increased bone mass is an unexpected phenotype associated with deletion of the calcitonin gene. Journal of Clinical Investigation 110 1849-1857. (doi:10.1172/JCI14218)

Judex S, Garman R, Squire M, Donahue LR \& Rubin C 2004 Genetically based influences on the site-specific regulation of trabecular and cortical bone morphology. Journal of Bone and Mineral Research 19 600-606. (doi:10.1359/JBMR.040101)

Mabilleau G, Chappard D \& Sabokbar A 2011 Role of the A20-TRAF6 axis in lipopolysaccharide-mediated osteoclastogenesis. Journal of Biological Chemistry 286 3242-3249. (doi:10.1074/jbc.M110.150300)

Madsen LW, Knauf JA, Gotfredsen C, Pilling A, Sjogren I, Andersen S, Andersen L, de Boer AS, Manova K, Barlas A et al. 2012 GLP-1 receptor agonists and the thyroid: C-cell effects in mice are mediated via the GLP-1 receptor and not associated with RET activation. Endocrinology 153 1538-1547. (doi:10.1210/en.2011-1864) 
Merchenthaler I, Lane M \& Shughrue P 1999 Distribution of pre-pro-glucagon and glucagon-like peptide-1 receptor messenger RNAs in the rat central nervous system. Journal of Comparative Neurology 403 261-280. (doi:10.1002/(SICI)1096-9861(19990111)403:2<261:: AID-CNE8 > 3.0.CO;2-5)

Mieczkowska A, Basle MF, Chappard D \& Mabilleau G 2012 Thiazolidinediones induce osteocyte apoptosis by a $\mathrm{G}$ protein-coupled receptor 40-dependent mechanism. Journal of Biological Chemistry $\mathbf{2 8 7}$ 23517-23526. (doi:10.1074/jbc.M111.324814)

Moonga BS, Alam AS, Bevis PJ, Avaldi F, Soncini R, Huang CL \& Zaidi M 1992 Regulation of cytosolic free calcium in isolated rat osteoclasts by calcitonin. Journal of Endocrinology 132 241-249. (doi:10.1677/ joe.0.1320241)

Nuche-Berenguer B, Moreno P, Esbrit P, Dapia S, Caeiro JR, Cancelas J, Haro-Mora JJ \& Villanueva-Penacarrillo ML 2009 Effect of GLP-1 treatment on bone turnover in normal, type 2 diabetic, and insulinresistant states. Calcified Tissue International 84 453-461. (doi:10.1007/ s00223-009-9220-3)

Nuche-Berenguer B, Moreno P, Portal-Nunez S, Dapia S, Esbrit P \& Villanueva-Penacarrillo ML 2010 Exendin-4 exerts osteogenic actions in insulin-resistant and type 2 diabetic states. Regulatory Peptides 159 61-66. (doi:10.1016/j.regpep.2009.06.010)

Oliver WC \& Pharr GM 1992 An improved technique for determining hardness and elastic modulus using load and displacement sensing indentation experiments. Journal of Materials Research 7 1564-1583. (doi:10.1557/JMR.1992.1564)

Paschalis EP, DiCarlo E, Betts F, Sherman P, Mendelsohn R \& Boskey AL 1996 FTIR microspectroscopic analysis of human osteonal bone. Calcified Tissue International 59 480-487.
Paschalis EP, Verdelis K, Doty SB, Boskey AL, Mendelsohn R \& Yamauchi M 2001 Spectroscopic characterization of collagen cross-links in bone. Journal of Bone and Mineral Research 16 1821-1828. (doi:10.1359/ jbmr.2001.16.10.1821)

Ritchie RO, Koester KJ, Ionova S, Yao W, Lane NE \& Ager JW III 2008 Measurement of the toughness of bone: a tutorial with special reference to small animal studies. Bone $\mathbf{4 3}$ 798-812. (doi:10.1016/ j.bone.2008.04.027)

Roschger P, Fratzl P, Eschberger J \& Klaushofer K 1998 Validation of quantitative backscattered electron imaging for the measurement of mineral density distribution in human bone biopsies. Bone 23 319-326. (doi:10.1016/S8756-3282(98)00112-4)

Turner CH \& Burr DB 1993 Basic biomechanical measurements of bone: a tutorial. Bone 14 595-608. (doi:10.1016/8756-3282(93)90081-K)

Wu T, Rayner CK, Jones K \& Horowitz M 2010 Dietary effects on incretin hormone secretion. Vitamins and Hormones 84 81-110. (doi:10.1016/ S0083-6729(10)84015-4)

Yamada C, Yamada Y, Tsukiyama K, Yamada K, Udagawa N, Takahashi N, Tanaka K, Drucker DJ, Seino Y \& Inagaki N 2008 The murine glucagonlike peptide-1 receptor is essential for control of bone resorption. Endocrinology 149 574-579. (doi:10.1210/en.2007-1292)

Zaidi M, Datta HK, Moonga BS \& MacIntyre I 1990 Evidence that the action of calcitonin on rat osteoclasts is mediated by two $G$ proteins acting via separate post-receptor pathways. Journal of Endocrinology 126 473-481. (doi:10.1677/joe.0.1260473)

Zioupos P, Currey JD \& Hamer AJ 1999 The role of collagen in the declining mechanical properties of aging human cortical bone. Journal of Biomedical Materials Research 45 108-116. (doi:10.1002/(SICI)10974636(199905)45:2 < 108::AID-JBM5 > 3.0.CO;2-A)

Received in final form 26 July 2013

Accepted 1 August 2013

Accepted Preprint published online 2 August 2013
(C) 2013 Society for Endocrinology Printed in Great Britain 